\title{
Efficient synthesis of dehydroamino acid derivatives
}

\author{
Paula M. T. Ferreira, Hernâni L. S. Maia* and Luís S. Monteiro \\ Department of Chemistry, University of Minho, Gualtar, 4710 Braga, Portugal
}

Received 10 June 1998; revised 8 October 1998; accepted 12 October 1998

\begin{abstract}
By using a DMAP catalysed reaction of $\beta$-hydroxyamino acid derivatives with tert-butylpyrocarbonate, the corresponding dehydroamino acid derivatives were obtained in high yields. 01998 Elsevier Science Ltd. All rights reserved.
\end{abstract}

\section{Introduction}

Naturally occurring compounds containing $\alpha, \beta$-dehydroamino acid residues are frequently encountered in many biologically important peptides, including the class of polycyclic peptide antibiotics known as lantibiotics (viz. nisin, epidermin, subtilin) and also several enzymes from plant and bacterial sources. Since they affect both chemical reactivity and conformation, dehydroamino acids have also been introduced into peptides for structure-activity relationship studies [1-4].

Several methods have been developed for the synthesis of dehydroamino acids $[1,2,5]$ but $\beta$ elimination has been the main approach to the synthesis of dehydroalanine $(\Delta \mathrm{Ala})$ and dehydroaminobutyric acid $(\triangle \mathrm{Abu})[2,3,6,7,8,9]$. Although this route has the advantage of starting from readily available serine and threonine derivatives, respectively, most of the $\beta$ elimination procedures described in the literature are accompanied by side reactions that may lead to complex mixtures, difficult purifications and poor yields. In the case of dehydroaminobutyric acid, the methyl group at the $\beta$-carbon atom gives rise to two geometrical isomers, $\mathrm{E}$ and $\mathrm{Z}$, the latter being the only one found in nature; this further complicates isolation and purification of the product required and leaves place for investigation of the possibility of obtaining conditions for stereoselective or even stereospecific dehydration.

\section{Results and discussion}

In previous work [10], we found that treatment of serine derivatives with benzyl chloroformate, DMAP and triethylamine in DMSO gives the corresponding dehydroalanine derivatives in fairly good yields $(51-76 \%)$. However, when attempting to use this method with threonine derivatives, a complex reaction mixture was obtained, failing to give any pure product. It was found by Nugent [11] that it was possible to dehydrate $\beta$-hydroxyamino acids by treatment with an excess of $\mathrm{Ac}_{2} \mathrm{O}$ in the presence of base. However, the yields were only fair $(\approx 60 \%)$. In view of these results, we considered increasing the size of the second group at $0040-4039 / 98 / \$$ - see front matter $C 1998$ Elsevier Science Ltd. All rights reserved.

PII: S0040-4039(98)02164-9 
the nitrogen atom of the $\beta$-hydroxyamino acid in order to facilitate $\beta$-elimination and thus improve the reaction yields. Hence, when reacting N,C-protected serine, threonine or $\beta$ hydroxyphenylalanine derivatives in dry acetonitrile with tert-butylpyrocarbonate in the presence of DMAP as catalyst, the only product isolated was the corresponding $\triangle \mathrm{Ala}, \triangle \mathrm{Abu}$ or dehydrophenylalanine ( $\triangle \mathrm{Phe}$ ) derivative (II, scheme 1). As shown in Table 1, in all cases but one, the starting material was previously protected with one of the following groups: tertbutyloxycarbonyl (Boc), benzyloxycarbonyl (Z), p-nitrobenzyloxycarbonyl [Z( $\left.\left(\mathrm{NO}_{2}\right)\right]$, diphenylphosphinyl (Dpp), $p$-toluenesulfonyl (Tos).<smiles>CCCC(NCC)C(=O)OC</smiles>

(I)<smiles>CCCCO[14CH3]</smiles>

(II)

$\mathrm{R}: \mathrm{H}, \mathrm{Me}, \mathrm{Ph}$

$\mathrm{R}_{1}: \mathrm{Boc}, \mathrm{Z}, \mathrm{Z}\left(\mathrm{NO}_{2}\right)$, Dpp, Tos

Scheme 1

Table 1

Results obtained in the synthesis of dehydroamino acid derivatives

\begin{tabular}{|c|c|c|}
\hline Reagent & Product & Yield $/ \%^{a}$ \\
\hline Boc-Ser-OMe & $\mathrm{Boc}-\Delta \mathrm{Ala}(N-\mathrm{Boc})-\mathrm{OMe}$ & 92 \\
\hline Z-Ser-OMe & $\mathrm{Z}-\Delta \mathrm{Ala}(N-\mathrm{Boc})-\mathrm{OMe}$ & 85 \\
\hline $\mathrm{Z}\left(\mathrm{NO}_{2}\right)$-Ser-OMe & $\mathrm{Z}\left(\mathrm{NO}_{2}\right)-\Delta \mathrm{Ala}(N-\mathrm{Boc})-\mathrm{OMe}$ & 93 \\
\hline Dpp-Ser-OMe & $\mathrm{Dpp}-\Delta \mathrm{Ala}(N-\mathrm{Boc})-\mathrm{OMe}$ & 88 \\
\hline Tos-Ser-OMe & Tos- $\Delta \mathrm{Ala}(N-\mathrm{Boc})-\mathrm{OMe}$ & 99 \\
\hline Boc-Ser-OH & $\mathrm{Boc}-\Delta \mathrm{Ala}(N-\mathrm{Boc})-\mathrm{O} t \mathrm{Bu}$ & 73 \\
\hline $\mathrm{Z}$-Ser-OH & $\mathrm{Z}-\Delta \mathrm{Ala}(N-\mathrm{Boc})-\mathrm{O} t \mathrm{Bu}$ & 65 \\
\hline $\mathrm{H}$-Ser-OMe & Boc- $\Delta \mathrm{Ala}(N-\mathrm{Boc})-\mathrm{OMe}$ & 82 \\
\hline Boc-Thr-OMe & $\operatorname{Boc}-\Delta \mathrm{Abu}(N-\mathrm{Boc})-\mathrm{OMe} \mathrm{e}^{\mathrm{b}}$ & 87 \\
\hline $\mathrm{Z}\left(\mathrm{NO}_{2}\right)$-Thr-OMe & $\mathrm{Z}\left(\mathrm{NO}_{2}\right) \Delta \mathrm{Abu}(N-\mathrm{Boc})-\mathrm{OMe} \mathrm{e}^{\mathrm{b}}$ & 92 \\
\hline Tos-Thr-OMe & Tos- $\triangle \mathrm{Abu}(N-\mathrm{Boc})-\mathrm{OMe}^{\mathrm{b}}$ & 87 \\
\hline Boc-Thr-OH & $\operatorname{Boc}-\Delta \mathrm{Abu}(N-\mathrm{Boc})-\mathrm{O} t \mathrm{~B} \mathrm{u}^{\mathrm{b}}$ & 73 \\
\hline $\mathrm{Z}\left(\mathrm{NO}_{2}\right)-\mathrm{Phe}(\beta-\mathrm{OH})-\mathrm{OMe}$ & $\mathrm{Z}\left(\mathrm{NO}_{2}\right)-\Delta \mathrm{Phe}(N-\mathrm{Boc})-\mathrm{OMe}^{\mathrm{b}}$ & 93 \\
\hline
\end{tabular}

An attempt to apply this methodology to an Fmoc derivative of serine failed to give Fmoc$\triangle \mathrm{Ala}(N$-Boc)-OMe due to base induced cleavage of Fmoc by the catalyst (DMAP); this group was substituted by a further Boc group and, thus, the only product obtained was Boc- $\triangle \mathrm{Ala}(N$ Boc)-OMe. In the case of $N$-trityl serine methyl ester the only product obtained was Trt-Ser $(O$ Boc)-OMe. This suggests that steric hindrance caused by the trityl group in this case does not 
allow further reaction at the nitrogen atom, which would be essential to induce elimination at the $\beta$-carbon atom. In fact, by sampling the reaction mixture throughout the preparation of $\mathrm{Z}\left(\mathrm{NO}_{2}\right)-\Delta \mathrm{Ala}(N-\mathrm{Boc})-\mathrm{OMe}$, it was found that the reaction proceeds through a three-step pattern, starting with binding of a tert-butyloxycarbonyl group at the amine function, followed by carboxylation of the hydroxyl group to give the corresponding tert-butylcarbonate, which undergoes $\beta$-elimination to the final product.

With threonine and $\beta$-hydroxyphenylalanine derivatives (threo type) the reaction was stereoselective, giving only the naturally occurring Z-isomer as shown by NMR spectroscopy. This selectivity seems to result from the bulkiness of the groups bound to the nitrogen atom, which would force and thus facilitate a trans $\mathrm{E}_{2}$-elimination. This is in agreement with results obtained by Srinivasan et al. [12] who have reported that base induced $\beta$-elimination of $N$-acyl$\mathrm{DL}-\mathrm{Thr}\left(O\right.$-Tos)-OMe (threo type) proceeds via a trans $\mathrm{E}_{2}$-elimination to give the $\mathrm{Z}$-isomer in a $70 \%$ yield.

Having in mind to simplify our procedure by saving one of the two required protection steps, the use of derivatives of serine and threonine bearing only one protecting group either at the $\mathrm{N}$ or the C-terminus was investigated. When a derivative with a free carboxyl function was used as starting material, it underwent a DMAP catalysed esterification with dicarbonate as described by Takeda et al. [13] to give the tert-butyl ester of the N-protected $N$-Boc dehydroamino acid as the only product obtained.

The Boc group can be easily removed selectively from the dehydroamino acid derivatives by treatment with TFA, as demonstrated in the cleavage of $\mathrm{Z}\left(\mathrm{NO}_{2}\right)-\Delta \mathrm{Abu}(N$-Boc)-OMe to give $\mathrm{Z}\left(\mathrm{NO}_{2}\right)-\triangle \mathrm{Abu}-\mathrm{OMe}$ in an $85 \%$ yield; the product thus obtained was then saponified, yielding $78 \%$ of $\mathrm{Z}\left(\mathrm{NO}_{2}\right)-\triangle \mathrm{Abu}-\mathrm{OH}$; finally this $\mathrm{N}$-protected dehydroamino acid was coupled with glycine methyl ester with the aid of DCC in a $74 \%$ yield.

The conditions usually required to cleave the Tos and $\mathrm{Z}\left(\mathrm{NO}_{2}\right)$ groups by standard procedures are possibly too drastic to be applied to dehydroamino acid derivatives. However, these groups were used as we wanted to investigate their cleavage from dehydroamino acids by the use of mild electrolysis, according to procedures previously developed in our laboratory $[14,15]$. Thus, Tos and $\mathrm{Z}\left(\mathrm{NO}_{2}\right)$ could be selectively removed by electrolysis at controlled potential from the respective dehydroaminobutyric acid derivatives to give Boc- $\triangle \mathrm{Abu}-\mathrm{OMe}$ in yields of $78 \%$ and $93 \%$, respectively.

The applicability of our methodology to the dehydration of peptides containing $\beta$ hydroxyamino acids was also investigated. The dipeptides Boc-Ala-Ser-OMe, Boc-Ala-ThrOMe and Boc-Phe-Phe $(\beta-\mathrm{OH})-\mathrm{OMe}$ were prepared and reacted under the conditions described previously to give $\mathrm{Boc}-\mathrm{Ala}(N$-Boc $)-\Delta \mathrm{Ala}(N$-Boc)-OMe, Boc-Ala $(N$-Boc)- $\Delta \mathrm{Abu}(N$-Boc)-OMe and $\operatorname{Boc}-\mathrm{Phe}(N$-Boc)- $\Delta \mathrm{Phe}(N$-Boc)-OMe with yields of 91,84 and $91 \%$ respectively. Again, the reaction of the dipeptides containing a $\beta$-hydroxyamino acid residue was stereoselective, the product containing only the $\mathrm{Z}$-isomer. Further investigation concerning dehydration of diand tripeptides is under way. 


\section{Conclusion}

The method reported above allows the high yielding preparation of a variety of dehydroamino acid derivatives, including peptides, by using mild reaction conditions and simple work-up procedures. In the case of $\beta$-hydroxyamino acids other than serine, this methodology offers the further advantage of leading only to the Z-isomer, which is the naturally occurring species. Selective cleavage of either Boc or Tos and $\mathrm{Z}\left(\mathrm{NO}_{2}\right)$ from the fully protected compounds was achieved in good yields to give the corresponding monoprotected esters. Our results make us believe that this is a general and stereoselective method for the preparation of the Z-isomer of derivatives, including peptides, of known or new $\alpha, \beta$ dehydroamino acids as obtained from direct dehydration of the corresponding $\beta$-hydroxy compounds. Such peptides would be of appreciable importance for pharmacological screening.

\section{General experimental procedure (example)}

Preparation of Tos- $\triangle \mathrm{Ala}(N$-Boc)-OMe: To a solution of Tos-Ser-OMe $(5 \mathrm{mmol})$ in dry acetonitrile $(5 \mathrm{ml})$, was added DMAP $(0.5 \mathrm{mmol})$ followed by tert-butylpyrocarbonate $(12.5$ $\mathrm{mmol}$ ) under rapid stirring at room temperature. The reaction was left for $12 \mathrm{~h}$, being monitored by t.l.c. (ethyl ether:hexane, 1:1). Evaporation at reduced pressure gave a residue that was partitioned between ethyl ether $(200 \mathrm{ml})$ and $\mathrm{KHSO}_{4} 1 \mathrm{M}(100 \mathrm{ml})$. The organic phase was thoroughly washed with $\mathrm{KHSO}_{4} 1 \mathrm{M}, \mathrm{NaHCO}_{3} 1 \mathrm{M}$ and saturated brine ( $3 \times 50 \mathrm{ml}$ each), and dried over $\mathrm{MgSO}_{4}$. Removal of the solvent afforded the required product. After crystallization (ethyl ether/hexane) a white solid was obtained in a $99 \%$ yield: m.p. $129-130^{\circ} \mathrm{C} ;{ }^{1} \mathrm{H} \mathrm{NMR}$ (300 MHz) $\delta\left(\mathrm{CDCl}_{3}\right): 1.3\left(9 \mathrm{H}, \mathrm{s}, \mathrm{CH}_{3} \mathrm{Boc}\right) ; 2.4$ (3H, s, $\left.\mathrm{CH}_{3} \mathrm{Tos}\right) ; 3.7$ (3H, s, $\mathrm{CH}_{3} \mathrm{OMe}$ ); 6.1 and $6.7\left(2 \mathrm{H}, 2 \mathrm{~s},=\mathrm{CH}_{2}\right) ; 7.3$ and $7.9\left(4 \mathrm{H}, 2 \mathrm{~d} \mathrm{~J}=8.6 \mathrm{~Hz}\right.$, ArH Tos).; Anal. Calc. for $\mathrm{C}_{22} \mathrm{H}_{21} \mathrm{NO}_{6} \mathrm{~S}$ (355.41): C 54.07; H 5.96; N 3.94; S 9.02, Found: C 54.34, H 6.11, N 3.93, S 8.86.

\section{References}

[1] Schmidı U. Hausler J. Olher E, Poisel H, Fortschr. Chem. Org. Naturst. 1977;37:251.

[2] Noda K, Shimohigashi Y, Izumiya N, The Peptides, Analysis, Synthesis, Biology, Vol. 5, New York: Academic Press, 1983:286.

[3] Schmidt U, Lieberknecht A, Wild J, Synthesis 1988:159.

[4] Jung G, Angew. Chem., Int. Ed. Engl. 1991;30:1051.

[5] Sommerfeld TL, Seebach D, Helv. Chim. Acta 1993;76:1702.

[6] Berti F, Ebert C, Gardossi L, Tetrahedron Lett. 1992;33:8145.

[7] Balsamini A, Duranti E, Mariani L, Salvatori A, Spadoni G, Synthesis 1990:779.

[8] Ranganathan D, Shah K. Vaish N, J. Chem. Soc., Chem. Commun. 1992:1145

19] Gondall K. Parsons AF. Tetrahedron Lett. 1995; 36:3259.

[10] Ferreira PMT, Maia HLS, Rodrigues LM, Peptides 1996, Proceedings of the 24th European Peptide Symposium", eds. R. Ramage and R. Epton, 1998:377.

[11] Nugent WA, Chemical Abstracts 1996: $143302 \mathrm{k}$

[12] Srinivasan A. Stephesen RW, Olsen RK, J. Org. Chem. 1977;42:2256.

113] Takeda K, Akiyama A, Nakamura H, Takizawa S, Mizuno Y, Takayanagi H, Harigaya Y, Synthesis 1994:1063.

[14] Grehn L, Gunnarsson K, Maia HLS, Montenegro MI, Pedro L, Ragnarsson U, J. Chem. Res. S 1988:399; J. Chem. Res. M 1988:3081.

[15] Grehn L, Maia HLS. Monteiro LS, Montenegro MI, Ragnarsson U, J. Chem. Res. S 1991:144; J. Chem. Res. M 1991:1501. 